\title{
Effect of peptide histidine valine on cardiovascular and respiratory function in normal subjects
}

\author{
E R CHILVERS, C M S DIXON, Y YIANGOU, S R BLOOM, P W IND
}

From the Department of Medicine, Royal Postgraduate Medical School, Hammersmith Hospital, London

ABSTRACT Non-adrenergic inhibitory nerves may have an important role in regulating airway $\overrightarrow{0}$ calibre. A recently discovered peptide, peptide histidine valine, is a potent relaxer of airway smooth muscle in vitro and has been proposed as a possible neurotransmitter in this tissue. The cardiovascular and respiratory effects of graded infusions of this peptide $\left(2 \cdot 5-10 \mathrm{pmol} \mathrm{kg}^{-1} \mathrm{~min}^{-1}\right)^{\circ}$ have been examined in six normal subjects in a placebo controlled, randomised double blind study $\vec{O}$ The mean (SEM) peak plasma concentration of peptide histidine valine during the highest infusion? rate was 2392 (170) pmol/1, representing a 29 fold increase above the basal concentration. This was: accompanied by flushing, a significant increase in heart rate of 28 (3.7) beats/min and skin temperature of $1.8^{\circ}\left(0 \cdot 16^{\circ}\right) \mathrm{C}$, but no effect on systolic or diastolic blood pressure. Despite these higho plasma concentrations of the peptide and the substantial tachycardia and increase in skin blood flow there was no change in partial expiratory flow at $40 \%$ of vital capacity $\left(\dot{V}_{40}\right)$ or in the airway response to inhaled histamine (geometric $\mathrm{PD}_{40} 9.37$ and $9.73 \mu \mathrm{mol}$ during saline and peptide histidine valine infusion respectively). Although these findings provide no support for a physiological role of peptiden histidine valine in controlling airway function in healthy subjects, important effects of locally released peptides in the vasoactive intestinal peptide family cannot be excluded.

\section{Introduction}

Non-adrenergic, non-cholinergic nerves have been recently identified in human airways ${ }^{1}$ and may be important in regulating certain aspects of airway function, including airway calibre, mucosal gland secretion, and pulmonary vascular resistance. ${ }^{2-4}$ In the absence of any substantial direct sympathetic innervation of human airway smooth muscle ${ }^{5}$ non-adrenergic inhibitory nerves form the only neurogenic pathway causing relaxation of airway smooth muscle. The neurotransmitters of some of these nerves remain uncertain, although immunocytochemical evidence ${ }^{6}$ and in vitro ${ }^{7}$ and in vivo studies ${ }^{89}$ suggest that vasoactive intestinal peptide (VIP) and peptide histidine methionine may play a part.

A novel 42 amino acid regulatory peptide, peptide histidine valine, was recently isolated from a human phaeochromocytoma and characterised, ${ }^{10}$ and subsequently found in mammalian airways. "It is closely related to vasoactive intestinal peptide and peptide histidine methionine, being derived from the same

Address for reprint requests: Dr E R Chilvers, Department of Thoracic Medicine, Cardiothoracic Institute, London SW3 $6 \mathrm{LY}$.

Accepted 4 July 1988 precursor peptide (prepro-VIP), with an amino acid sequence corresponding exactly to prepro-VIP-81-12\$. (fig 1). In vitro peptide histidine valine appears to be more potent than either vasoactive intestinal peptide or peptide histidine methionine in relaxing guinea pig tracheal smooth muscle ${ }^{10}$ and is therefore the mose active endogenous relaxant of airway smooth muscle known.

In normal volunteers vasoactive intestinal peptide, infused at $6 \mathrm{pmol} \mathrm{kg}^{-1} \mathrm{~min}^{-1}$, has no effect on airway calibre. ${ }^{12}$ We have now infused higher doses of peptides histidine valine in normal subjects and investigated the possible physiological role of this peptide in man bro studying its effects on cardiovascular and respiratory function.

\section{Methods}

We studied six healthy, non-asthmatic subjects (fivह male; mean age 30 years) (table). Incremental peptidé histidine valine and saline infusions were administered on separate days, at the same time of day, according $t \bar{Q}$ a randomised double blind design. The two study days were separated by a minimum of one week. Approva for this study was obtained from the Hammersmit Hospital ethical committee and all subjects gave written informed consent. 


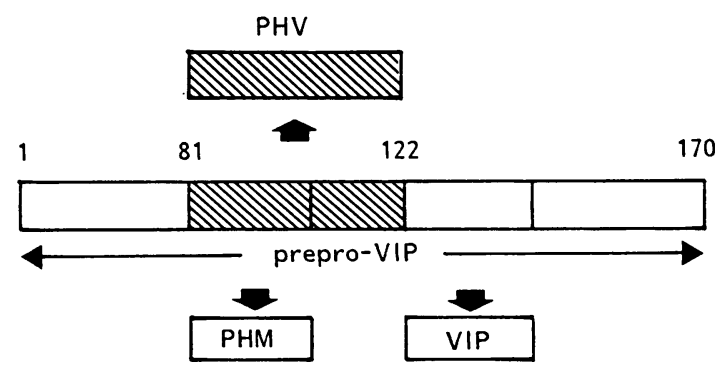

Fig 1 Peptide histidine valine ( $P H V)$, peptide histidine methionine (PHM), and vasoactive intestinal peptide (VIP) are all derived from a single 170 amino acid peptide called prepro-VIP. The variable post translational processing required to obtain the individual active peptides is shown with PHV resulting from cleavage at the 88 and 122 amino acid positions as indicated.

\section{CARDIOVASCULAR MEASUREMENTS}

Heart rate recordings were made with continuous display electrocardiography (Hewlett Packard, Waltham, USA) and the number of QRS complexes occurring in 60 seconds was counted. Blood pressure was measured indirectly with an automatically inflating sphygmomanometer (Dinamap, Critikon, USA). The mean of two measurements was recorded at each time point. Skin temperature was measured by means of a thermistor (Hewlett Packard), with a response time of seven seconds, placed on the left cheek.

\section{RESPIRATORY MEASUREMENTS}

Airway calibre was measured by recording airflow at $60 \%$ of vital capacity below total lung capacity, measured from total lung capacity after a forced partial expiratory flow manoeuvre $\left(\dot{\mathrm{V}}_{40}\right)$ with a rolling seal spirometer (PK Morgan, Chatham) connected to a microcomputer. The mean of two measurements was recorded. For the histamine challenge test subjects initially inhaled five breaths of $0.9 \%$ normal saline from a compressed air nebuliser controlled by a breath activated dosimeter (Mefar, Brescia, Italy), which was followed after 30 seconds by measurement of $\dot{\mathrm{V}} \mathrm{p}_{40}$. This procedure was repeated after subjects had inhaled

\section{Characteristics of the patients}

\begin{tabular}{|c|c|c|c|c|c|c|}
\hline $\begin{array}{l}\text { Subject } \\
\text { No }\end{array}$ & $\begin{array}{c}\text { Age } \\
(y)\end{array}$ & Sex & $\begin{array}{l}\text { Weight } \\
(\mathrm{kg})\end{array}$ & Atopy & $\begin{array}{l}\dot{V} p_{10} \\
\text { baseline } \\
(\text { l/min })\end{array}$ & 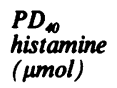 \\
\hline $\begin{array}{l}1 \\
2 \\
3 \\
4 \\
5 \\
6\end{array}$ & $\begin{array}{l}29 \\
40 \\
27 \\
36 \\
22 \\
24\end{array}$ & $\begin{array}{l}\mathbf{M} \\
\mathbf{M} \\
\mathbf{M} \\
\mathbf{M} \\
\mathbf{M} \\
\mathbf{F}\end{array}$ & $\begin{array}{l}75 \\
82 \\
72 \\
76 \\
79 \\
53\end{array}$ & $\begin{array}{l}- \\
\bar{t} \\
+ \\
+\end{array}$ & $\begin{array}{l}162 \\
122 \\
172 \\
224 \\
195 \\
192\end{array}$ & $\begin{array}{r}5 \cdot 1 \\
4.3 \\
16.9 \\
9.6 \\
15.4 \\
12.4\end{array}$ \\
\hline
\end{tabular}

five breaths of each concentration of histamine (doubling concentrations from 4 to $64 \mathrm{mg} / \mathrm{ml}$ ) until a greater than $40 \%$ fall in the post-saline $V \mathrm{p}_{40}$ was recorded. From these values the provocative dose of histamine causing a $40 \%$ fall in $\mathrm{VP}_{40}\left(\mathrm{PD}_{40}\right)$ was interpolated.

\section{PLASMA PEPTIDE HISTIDINE VALINE CONCENTRATIONS}

At each sample time $10 \mathrm{ml}$ of venous blood was taken, placed into chilled heparin tubes containing $4000 \mathrm{KIU}$ of Trasylol (Bayer UK Ltd, Newbury), centrifuged, and stored at $-20^{\circ} \mathrm{C}$. Plasma samples were assayed by means of a specific radioimmunoassay ${ }^{10}$ with antibody SY1.

\section{STUDY PROTOCOL}

Subjects were studied supine in an air conditioned room with a constant temperature of $21^{\circ} \mathrm{C}$ and had refrained from caffeinated drinks on the day of the study. Intravenous cannulas were placed in both antecubital fossae, and after the subjects had rested for 20 minutes baseline cardiovascular and respiratory measurements were made and blood was taken for peptide histidine valine assay. Subjects then received a 30 minute saline infusion followed by the active peptide or matched saline infusion. The infusions were prepared in a total volume of $50 \mathrm{ml}$ containing $10 \mathrm{ml}$ of the subject's own blood to reduce peptide adherence to the syringe and tubing. The starting concentration of the infusion was $2.5 \mathrm{pmol} \mathrm{kg}^{-1} \mathrm{~min}^{-1}$ for five minutes;

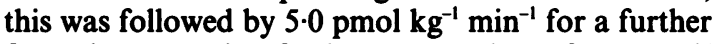
five minutes and a final concentration of $10 \mathrm{pmol} /$ $\mathrm{kg}^{-1} \mathrm{~min}^{-1}$ for 30 minutes. Measurements of heart rate, blood pressure, skin temperature, and airway diameter were made one and five minutes after each change in infusion rate and at five minute intervals during the highest concentration. Blood samples for peptide histidine valine assay were taken at 10 minute intervals throughout the study period with additional samples at the end of the 2.5 and $5 \mathrm{pmol} \mathrm{kg}^{-1} \mathrm{~min}^{-1}$ infusion periods. Fifteen minutes from the start of the high dose infusion an inhaled histamine challenge was performed. Further cardiovascular and respiratory measurements were made for 15 minutes after the end of the infusion.

Two subjects (Nos 3 and 6) were studied on a third day in a single blind design with a similar protocol except that they received a higher dose of peptide histidine valine, $20 \mathrm{pmol} \mathrm{kg}^{-1} \mathrm{~min}^{-1}$, which was maintained for 30 minutes. On these two study days the subjects were pretreated with $100 \mathrm{mg}$ atenolol orally four hours before the study to limit cardiovascular side effects, notably the tachycardia. Limited availability of peptide histidine valine prevented further studies at this higher dose. 


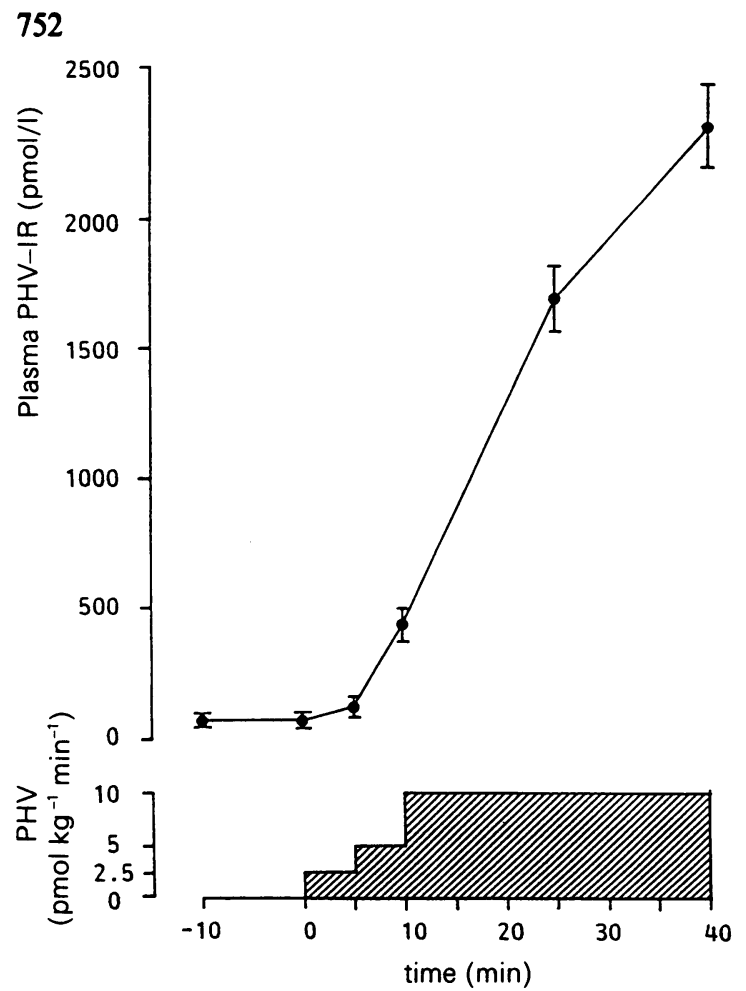

Fig 2 Plasma peptide histidine valine ( $\mathrm{PHV}$ )

concentrations (means with standard errors) achieved during PHV infusion. The shaded area indicates the infusion protocol. PHV was measured as PHV immunoreactivity as outlined in the text.

\section{DATA ANALYSIS}

Results in the text are expressed as means with standard errors in parentheses. For statistical analysis we used analysis of variance of repeated measurements and Student's $t$ test. $\dot{\mathrm{V}} \mathrm{p}_{40}$ data are expressed as geometric mean values with $95 \%$ confidence intervals and compared by means of the Mann-Whitney $U$ test after logarithmic transformation.

\section{Results}

Subjects tolerated the infusions well and all received the highest concentration of histidine valine of $\mathbf{1 0}$ $\mathrm{pmol} \mathrm{kg}^{-1} \mathrm{~min}^{-1}$. Mild flushing was the only reported side effect. The mean (SEM) plasma peptide histidine valine concentration increased from a basal value of $81.5(8)$ to $2392(170) \mathrm{pmol} / 130$ minutes after the start of the $10 \mathrm{pmol} \mathrm{kg}^{-1} \mathrm{~min}^{-1}$ infusion (fig 2). A significant increase in plasma peptide histidine valine concentration was seen five minutes after the start of the 2.5 and $5.0 \mathrm{pmol} \mathrm{kg}^{-1} \mathrm{~min}^{-1}$ infusion rates $(\mathrm{p}<0.05)$.

The effect of infused peptide histidine valine on the

Chilvers, Dixon, Yiangou, Bloom, Ind $\stackrel{\times}{*}$

cardiovascular measurements is shown in figure 3. The graded infusion caused a progressive increase in hearto rate, which reached a maximum of 28 (3.7) beats/min $(p<0.05)$ immediately before the histamine $\frac{\bar{\rho}}{\bar{C}}$ challenge. The tachycardia first achieved statistical ${ }_{\Omega}^{\Phi}$ significance five minutes after the start of the 5 pmolp $\mathrm{kg}^{-1} \mathrm{~min}^{-1}$ infusion, when the mean plasma peptide $\overrightarrow{ }$ histidine valine concentration was $438 \mathrm{pmol} / \mathrm{l}$. The increase in heart rate appeared to plateau with increas- $\vec{\omega}$ ing plasma concentrations of the peptide, little further $\stackrel{\rho}{S}$ increase occurring with plasma concentrations over $\overrightarrow{\vec{x}}$ $1500 \mathrm{pmol} / \mathrm{l}$. Peptide histidine valine caused a progres- $\frac{\dot{+}}{\omega}$ sive increase in skin temperature, with a maximum rise of $1.8^{\circ}\left(0.16^{\circ}\right) \mathrm{C}(\mathrm{p}<0.05) 15$ minutes after the start of $\bigcirc$ the $10 \mathrm{pmol} / 1$ infusion, before the administration of $\mathrm{O}$
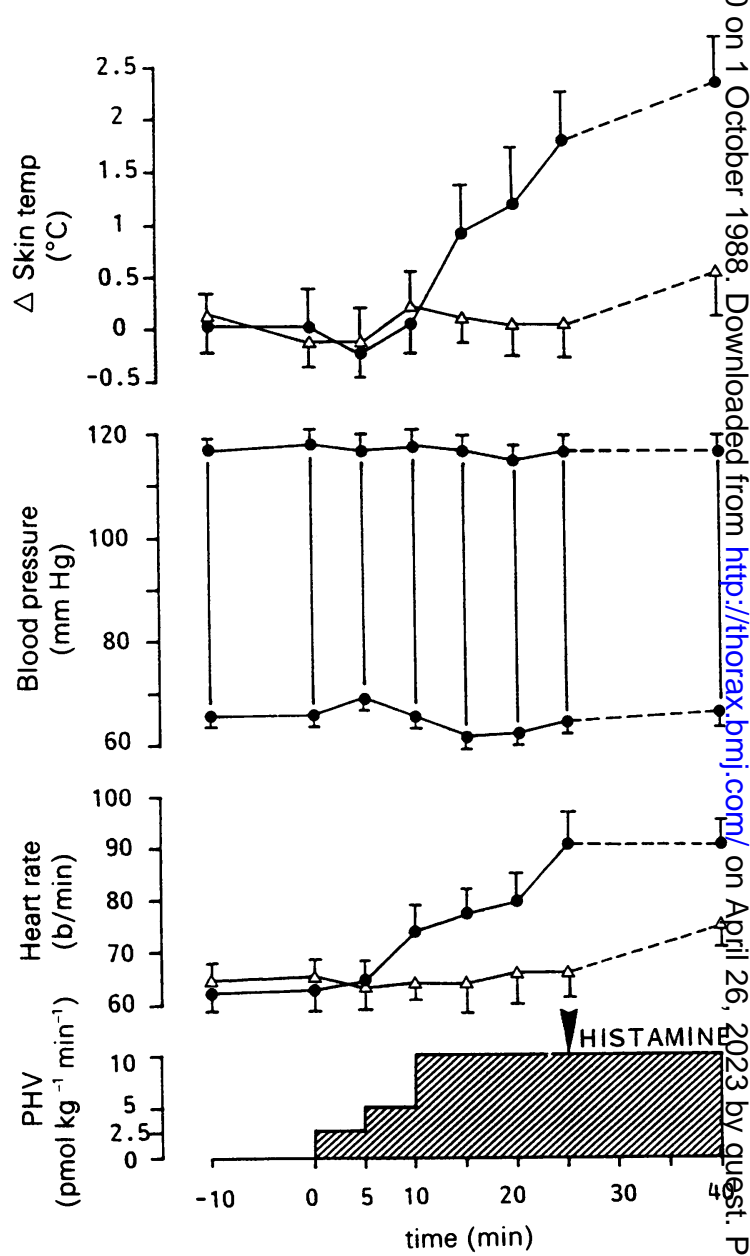

Fig 3 Cardiovascular effects of infused peptide histidine valine (PHV) (O) and saline control $(\triangle)$ (means with standard errors). Blood pressure values during the saline infusion are not included as they are virtually identical to those shown for the PHV infusion day. The arrow indicates the start of the histamine challenge. 


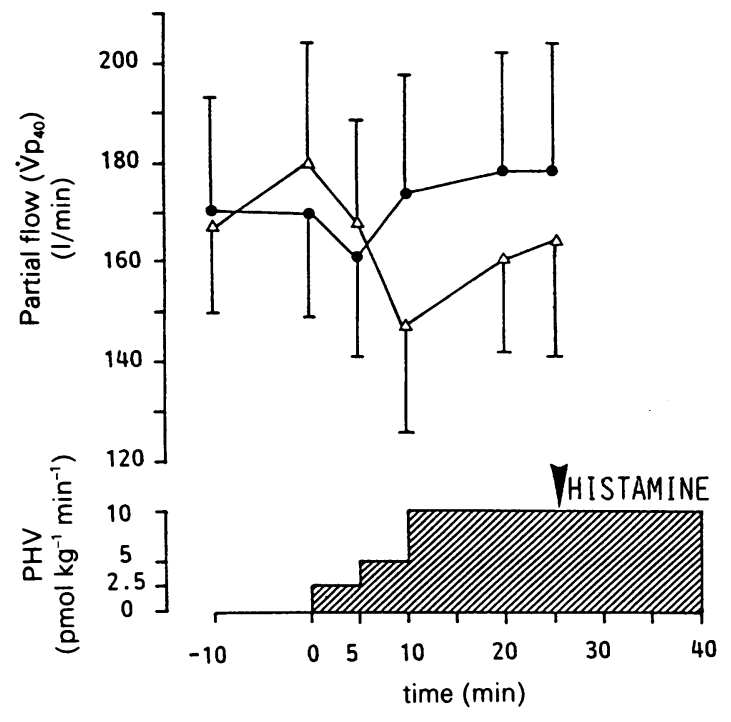

Fig 4 Effect of peptide histidine valine (PHV) (O) and saline control $(\triangle)$ infusion on airway calibre $\left(\dot{V} p_{40}\right.$, means with standard errors) before histamine challenge (indicated by the arrow).

histamine. Despite these substantial effects on heart rate and skin temperature no change was observed in either systolic or diastolic blood pressure during the infusion of the peptide (fig 3).

Peptide histidine valine caused no change in $\mathrm{Vp}_{40}$ at any infusion rate in any subject (fig 4). Inhalation of $800 \mu \mathrm{g}$ isoprenaline from a metered dose inhaler by the same subjects caused an increase in mean $\mathrm{Vp}_{40}$ of $57 \%$ $(8 \%)$. The mean coefficient of variation of the $V p_{40}$ values obtained during placebo infusion was $11 \%$ within subjects. All subjects had a greater than $\mathbf{4 0 \%}$ fall in $\mathrm{Vp}_{40}$ during the histamine challenge. The geometric mean $\mathrm{PD}_{40}$ histamine was $9.37 \mu \mathrm{mol}(95 \%$ confidence interval 5.85-15.01) during the saline infusion and $9.73 \mu \mathrm{mol}(6 \cdot 2-15 \cdot 26)$ during the peptide infusion (fig 5). This difference was not significant.

The two subjects who received peptide histidine valine $20 \mathrm{pmol} \mathrm{kg}^{-1} \mathrm{~min}^{-1}$ had increases of $27 \%$ and $24 \%$ in $\mathrm{V}_{\mathrm{p} 0}$ over baseline values after 15 minutes of this infusion. This compared with no increase and a $13 \%$ increase 15 minutes from the start of the $10 \mathrm{pmol}$ $\mathbf{k g}^{-1}$ min $^{-1}$ infusion on the previous study day. $\mathbf{P D}_{40}$ histamine values were increased from 12.3 and 16.9

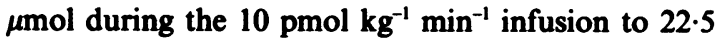
and $24 \cdot 3 \mu \mathrm{mol}$ during the $20 \mathrm{pmol} \mathrm{kg}^{-1} \mathrm{~min}^{-1}$ infusion in the two subjects.

\section{Discussion}

Infusion of peptide histidine valine in doses of up to 10 pmol $\mathrm{kg}^{-1} \mathrm{~min}^{-1}$ caused a dose dependent increase in heart rate and skin temperature but had no effect on systolic or diastolic blood pressure or on airway calibre in these normal subjects. The plasma levels of the peptide achieved in this study are some 20 fold higher than the plasma concentrations of vasoactive intestinal peptide produced by infusion in a similar study and represent a 29 fold increase over basal peptide histidine valine concentrations. ${ }^{12}$ This reflects the relatively long half life of the peptide when infused. ${ }^{13}$ Despite these high plasma concentrations and the potency of peptide histidine valine in relaxing airway smooth muscle in vitro (PHV $>$ VIP $>$ adrenaline), ${ }^{10}$ we have been unable to find any effect on resting airway calibre or histamine responsiveness in normal subjects at this dose. The large changes in $\dot{V} p_{40}$ values seen after the administration of a beta agonist and the small intrasubject variability of the measurement indicate that this measurement is a sensitive index of airway calibre and that small changes should have been detected.

These findings are in keeping with a similar lack of effect of infused vasoactive intestinal peptide on airway function in normal subjects, ${ }^{12}$ although a small bronchodilator response has been reported in asthmatic subjects. ${ }^{8}$ The dose of vasoactive intestinal peptide given by infusion is limited by the reduction in systolic blood pressure, and in the above study ${ }^{12}$

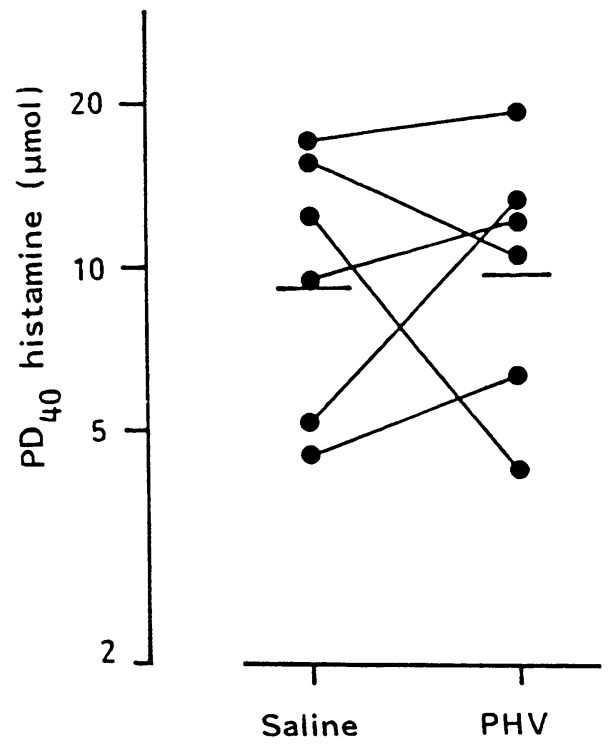

(10 pmol kg-1 $\left.\mathrm{min}^{-1}\right)$

Fig 5 Histamine responsiveness ( $\left.P D_{10}\right)$ during saline infusion and 15 minutes from the start of the peptide histidine valine ( $\mathrm{PHV}$ ) infusion $\left(10 \mathrm{pmol} \mathrm{kg}^{-1} \mathrm{~min}^{-1}\right)$. Each point represents the value for one subject and the horizontal lines indicate geometric mean values. 
plasma concentrations of only $34.6 \mathrm{pmol} / 1$ were

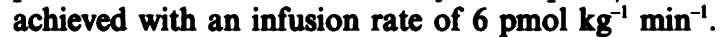
Nevertheless, there is now considerable evidence from in vitro studies suggesting that this peptide may function as a neurotransmitter of non-adrenergic inhibitory nerves in man. ${ }^{14}$ The failure to detect an effect on airway tone when peptide histidine valine or vasoactive intestinal peptide is infused in man may be due to the problem of access of the peptide to its airway receptor. This may be due in part to rapid enzymatic breakdown in the tissues. This should be less with peptide histidine valine as its plasma half life is about $\mathbf{5 0}$ times greater than vasoactive intestinal peptide in man..$^{13}$ In addition, extremely high circulating concentrations may be necessary to achieve concentrations of the peptide at airway receptors comparable to those that are possible after local peptide release from nerve terminals. Inhaled vasoactive intestinal peptide has been shown to afford protection against histamine induced bronchoconstriction only in those with atopic asthma9 and thus the possibility of an effect of peptide histidine valine administered by this route, particularly in individuals with asthma, cannot be discounted.

To examine the possibility that an airway effect might occur with a higher dose of peptide histidine valine, two subjects were studied on a third day with a higher dose, $20 \mathrm{pmol} \mathrm{kg}^{-1} \mathrm{~min}^{-1}$, of infused peptide histidine valine and a similar protocol. Although this study was uncontrolled, the increase in $\mathrm{Vp}_{40}$ and $\mathbf{P D}_{40}$ histamine in both subjects suggests that infused peptide histidine valine has the potential, at higher doses, to cause bronchodilatation.

The cardiovascular effects of infused peptide histidine valine in producing a considerable tachycardia and increase in skin temperature, but no change in blood pressure, are intriguing. In this respect the effect of peptide histidine valine is quite distinct from vasoactive intestinal peptide and peptide histidine methionine, which at much lower plasma concentrations, and for the same degrees of change in heart rate and skin temperature, produce substantial falls in diastolic and to a lesser extent in systolic blood pressure..$^{13}$ A direct chronotropic effect of peptide histidine valine on the heart has been proposed, ${ }^{13}$ but its apparent lack of effect on arteriolar resistance while it is dilating skin vessels is unexplained.

The physiological role of peptide histidine valine is uncertain. In addition to its effects on airway smooth muscle in vitro it is a potent relaxer of guinea pig gastric smooth muscle and reduces the force and frequency of spontaneous uterine contractions in the rat. ${ }^{10}$ It has been identified in mammalian nasal mucosa, stomach, genitalia, and airways. ${ }^{11}{ }^{15}$ In man, normal circulating concentrations of the peptide in the resting state are around $80 \mathrm{pmol} / \mathrm{l}$. It is the major circulating peptide in patients with VIPomas, with concentrations 10 times higher than those of vasoactive intestinal peptide or peptide histidine meth- $\frac{\bar{O}}{\bar{c}}$ ionine, and it may be responsible for the profuse $\overrightarrow{\widetilde{\sigma}}$ diarrhoea and other clinical features seen in patients $\bigcirc$ with these tumours. ${ }^{16}$

The possible role of peptide histidine valine as $a \vec{\circ}$ neurotransmitter of non-adrenergic nerves in airway $\overrightarrow{-}$ smooth muscle needs further investigation. Although $\vec{\rho}$ no significant effect on airway calibre or histamine responsiveness was seen at infusion rates up to $10 \mathrm{pmol}^{\times}$ $\mathrm{kg}^{-1} \mathrm{~min}^{-1}$, higher doses may result in a small increase $\stackrel{+}{\omega}$ in both these measurements. Our study does not rule $\vec{\circ}$ out an effect of locally released peptide histidine or valine. The close relationship of this peptide to vasoactive intestinal peptide and peptide histidine $\frac{}{3}$ methionine, its powerful pharmacological actions in vitro, and its localisation in airway tissue indicate that it may have a role in regulating airway function.

\section{References}

1 Richardson JB, Beland J. Nonadrenergic inhibitory nerves in human airways. J Appl Physiol 1976;41:ڤ 764-71.

2 Davis C, Kannan MS, Jones TR, Daniel EE. Control of human airway smooth muscle: in vitro studies. $J$ Applo Physiol 1982;53:1080-7.

3 Peatfield AC, Richardson PS. Evidence for non-cholinergic, non-adrenergic nervous control of mucus secretion. into the cat trachea. J Physiol 1983;342:335-45.

4 Hamasaki Y, Said SI. Evidence for a non-adrenergic, non-cholinergic inhibitory nervous system in cat pul- $x$ monary artery [abstract]. Clin Res 1981;29:550A.

5 Dodge JM, Satchell DG. Adrenergic and non-adrenergic. inhibitory nerves in mammalian airways. J Auton Nervo Syst 1982;5:83-99.

6 Dey RD, Shannon WA, Said SI. Localization of VIP-O immunoreactive nerves in airways and pulmonary vessels of dogs, cats and human subjects. Cell Tissue $\frac{D}{O}$ Res 1981;220:231-8.

7 Said SI, Kitamura S, Yoshida T, Preskitt J, Holden LD.N Humoral control of airways. Ann NY Acad Sci 1974;221:102-14.

8 Barnes PJ, Dixon CMS. The effect of inhaled vasoactive intestinal peptide on bronchial reactivity to histamineo in humans. Am Rev Respir Dis 1984;130:162-6.

9 Morice A, Unwin RJ, Sever PS. Vasoactive intestina peptide causes bronchodilatation and protects againstion histamine-induced bronchoconstriction in asthmatic subjects. Lancet 1983;ii:1225-6.

10 Yiangou $Y$, Di Marzo V, Spokes RA, Panico $M \stackrel{\text { Pे }}{\stackrel{O}{D}}$ Morris HR, Bloom SR. Isolation, characterization and? pharmacological actions of peptide histidine valine $42 \mathbb{Q}$ a novel prepro-vasoactive intestinal peptide-derivedo peptide. J Biol Chem 1987;262:14010-3.

11 Ghatei MA, Springall DR, Richards IM, et alo 
Regulatory peptides in the respiratory tract of Macaca fascicularis. Thorax 1987;42:431-9.

12 Palmer JBD, Cuss FMC, Warren JB, Blank M, Bloom SR, Barnes PJ. Effect of infused vasoactive intestinal peptide on airway function in normal subjects. Thorax 1986;41:663-6.

13 Gill JS, Yiangou Y, Chrysanthou BJ, et al. Peptide histidine valine: cardiovascular actions and pharmacokinetics in man differ from vasoactive intestinal peptide and peptide histidine methionine. Clin Sci (in press).
14 Anonymous. NANC nerves in airways [editorial]. Lancet 1986;ii:1253-4.

15 Yiangou Y, Requejo F, Polak JM, Bloom SR. Characterization of a novel prepro VIP derived peptide. Biochem Biophys Res Commun 1986;139:1142-9.

16 Yiangou Y, Williams SJ, Bishop AE, Polak JM, Bloom SR. Peptide histidine-methionine immunoreactivity in plasma and tissue in patients with vasoactive intestinal peptide-secreting tumours and watery diarrhoea syndrome. J Clin Endocrinol Metab 1987;64:131-9. 